\begin{tabular}{lc}
\hline & ANNALES \\
& UNIVERSITATIS MARIAE CURIE-SKŁODOWSKA \\
LOL. V & SECTIO N \\
\hline
\end{tabular}

ISSN: 2451-0491 • e-ISSN: 2543-9340 - CC-BY 4.0 • DOI: 10.17951/en.2020.5.117-130

\title{
Postać literacka jako przedmiot rozmyślań aksjologicznych
}

\section{Literary Character as a Subject of Axiological Reflections}

\author{
Danuta Łazarska \\ Uniwersytet Pedagogiczny im. Komisji Edukacji Narodowej w Krakowie. \\ Instytut Filologii Polskiej \\ ul. Podchorążych 2, 30-084 Kraków, Polska \\ danuta.lazarska@up.krakow.pl \\ http://orcid.org/0000-0003-0930-0969
}

\begin{abstract}
The starting point for the author's reflections in the article is axiology and literary character. The author discusses the significance of literary character in the process of opening teenagers up to axiological considerations. She also draws on some hitherto unpublished results of research conducted among future teachers. While referencing stories from the two volumes of Dark Chocolate (Pol. Gorzka czekolada), the author pays particular attention to the story Master's Girlfriend (Pol. Dziewczyna mistrza) by Katarzyna Ryrych - its protagonists and how they might stimulate the students to serious axiological ponderings. The article concludes with a handful of insights on the role of axiological education in the class, and the value of students' encounters with a variety of literary characters.
\end{abstract}

Keywords: axiology; literary character; axiological education

\footnotetext{
Abstrakt. Autorka artykułu wychodzi od rozważań na temat aksjologii i postaci literackiej. Omawia rolę postaci w otwieraniu nastolatków na rozważania aksjologiczne. Sygnalizuje też wybrane i niepublikowane dotąd rezultaty badań, które przeprowadziła wśród przyszłych nauczycieli. Odwołując się do opowiadań zamieszczonych w dwóch tomach Gorzkiej czekolady, uwagę poświęca Dziewczynie mistrza Katarzyny Ryrych - występującym w niej postaciom i ich znaczeniu dla
} 
rozbudzania namysłu uczniów nad ważnymi aksjologicznie sprawami. Całość zamykają refleksje nad edukacją aksjologiczną i wartością lekcyjnych spotkań z postaciami literackimi.

Słowa kluczowe: aksjologia; postać literacka; edukacja aksjologiczna

\section{WPROWADZENIE}

Aksjologia jest nauką o wartościach i kryteriach wartościowania, o konkretnym systemie aksjologicznym, który przyjmuje się w ramach jakiegoś poglądu jako (1) warunek oceny ludzi, ich zachowania, (2) miara dostrzeżonych zjawisk, (3) fundament budowania obowiązujących norm w życiu osobistym i społecznym człowieka (Dubisz red. 2006: 38). Nie od dzisiaj wiadomo, że problematyka aksjologii, dotycząca tego wszystkiego, co wiąże się z wartościami, od dawna jest przedmiotem licznych studiów i badań interdyscyplinarnych. Świadczą o tym chociażby typologie i hierarchie wartości stworzone przez znawców różnych dyscyplin naukowych, np. Maxa Schelera, Miltona Rokeacha, Jadwigę Puzyninę. Do grona specjalistów zajmujących się wartościami i ich obecnością w edukacji szkolnej oraz znaczeniem dla młodego człowieka należy zaliczyć polonistów uniwersyteckich, których badania ukierunkowane są na dydaktykę przedmiotu. W tej grupie znajdują się m.in. Bożena Chrząstowska, Ryszard Jedliński, Małgorzata Karwatowska, Urszula Kopeć, Paweł Sporek. Zdaniem Henryka Kurczaba (2012: 8), pochylającego się nad zagadnieniami aksjologii w edukacji polonistycznej, jednym z ważniejszych zadań tej ostatniej „jest poszukiwanie wartości wokół siebie, w sobie poprzez kontakt z dziełem literackim". O potrzebie podejmowania refleksji aksjologicznych podczas lekcyjnych spotkań młodego pokolenia z utworami oraz o roli tych ostatnich w jego kształceniu i wychowaniu piszą również np. Maria Kwiatkowska-Ratajczak (1994) czy autorzy artykułów zawartych w publikacji pt. Wartościowanie a edukacja polonistyczna (Janus-Sitarz red. 2008).

Zainteresowanie dociekaniami sprofilowanymi aksjologicznie nie słabnie. Wiąże się to zarówno ze światem współczesnym, w którym wyraźna jest dominacja antywartości, jak i z samą aksjologią jako nauką. Zdaniem Władysława Tatarkiewicza, który łączył tę ostatnią z teorią poznania i wartościowaniem m.in. zjawisk etycznych czy estetycznych, aksjologia podąża do odpowiedzi na dwa zasadnicze pytania: 1) Co to jest dobro? 2) Co jest dobre? Pierwsze zagadnienie koncentruje się na definicji i teorii wartości (wyjaśniającej pojęcie, sposób poznania i istnienia wartości), a drugie - na systematyzacji wartości (ich klasyfikacji i hierarchizacji). Pierwsze pytanie zmierza do tego, aby ustalić znaczenie wartości i ją opisać, drugie zaś do określenia porządku wartości. Aksjologia posiada więc 
warstwę teoretyczną i warstwę oceniającą - teoria wartości jest punktem wyjścia, fundamentem aksjologii, ale to przedstawienie uporządkowanej listy wartości jest jej zadaniem głównym (zob. Wiśniewski 1989: 291-292)ํ․․

Trzeba się zgodzić też z Józefem Tischnerem (1982: 483), który twierdził, że wszelkie kwestie aksjologiczne są rozważane od strony przedmiotów posiadających konkretną wartość oraz przez pryzmat osoby ludzkiej. Ta ostatnia myśli według wartości, wcześniej jednak je przeżywa i ich doświadcza, jednocześnie funkcjonując na co dzień w przestrzeni i spotykając się także z antywartościami, którymi czasami się kieruje. Doznawanie wartości, odczuwanie ambiwalentnych emocji z nimi związanych może zarówno fascynować, jak i frustrować. Wszystko to jest podstawą namysłu nad własną osobą oraz sensem i rolą wartości w życiu konkretnego Ja. Dzieje się tak dlatego, że zdaniem przywołanego filozofa „[a]ksjologia wyrasta z samego rdzenia tego, kim jestem” (tamże: 487). Budowanie refleksji nad samym sobą ma zatem sens wówczas, gdy staje się najpierw rozpoznawaniem własnej osoby, a dopiero potem wyjściem ku drugiemu podmiotowi. Realizacja tego zadania jest możliwa, gdy jednostka umie analizować i interpretować siebie i świat swoich wartości oraz odczytywać własne $J a$ w spotkaniu z Ty. Motywuje "to człowieka do nieustannej wewnętrznej aktywności, ciągłego procesu stawania się, rozwoju i zmiany. Kreacja samego siebie staje się sensem całego życia ku wartościom uznanym przez człowieka za najważniejsze" (Kurczab 2012: 8).

Pretekstem do wykonania tej dość trudnej obligacji mogą być postaci literackie. Celem artykułu jest omówienie ich roli w otwieraniu młodych czytelników na rozważania aksjologiczne w świetle wybranych efektów badań empirycznych, przeprowadzonych wśród przyszłych nauczycieli polonistów, oraz na przykładzie najnowszej literatury młodzieżowej.

\section{O POSTACI LITERACKIEJ I BADANIACH EMPIRYCZNYCH}

Postać literacka, jak wiadomo, jest wytworem wyobraźni pisarza, a jej losy stanowią zasadniczy element fabuły. Zaliczanie jej do świata fikcji nie oznacza jednak braku podobieństwa do ludzi rzeczywistych (Kasperski 1998: 35). Podejmując rozważania na temat postaci, trzeba mieć na uwadze indywidualny antropomimetyczny układ cech jakościowych i relacyjnych, nazywanych bezpośrednio lub wskazywanych pośrednio - implikowanych bądź sugerowanych

1 Ryszard Wiśniewski (1989) odwołuje się tu do referatu wygłoszonego przez Tatarkiewicza w 1947 roku. 
przez inne cechy i stany zewnętrzne, treści psychiczne, stosunki z innymi przedmiotami przedstawionymi (Markiewicz 1996: 167).

Układ, o którym mowa, coraz bardziej się rozrasta, kształtuje i unaocznia wraz z wchodzeniem czytelnika w głąb tekstu. Warto zatem uznać, że wpływ na postrzeganie przez niego postaci ma sposób jej przedstawienia w tekście. Może być on bezpośredni i pośredni. Pierwszy polega na określaniu wprost atrybutów postaci, natomiast drugi „to podawanie informacji, z których te właściwości można wywnioskować” (Markiewicz 1981: 155). Nie bez znaczenia w postrzeganiu postaci jest też sam proces czytelniczej recepcji dzieła, silnie powiązany z oddziaływaniem bohatera na rzeczywistość pozaliteracką, na odbiorcę tekstu. Warto przypomnieć, że postać odgrywa w utworze również jeszcze dwie role: „1) wobec innych składników czy aspektów dzieła literackiego, 2) wobec postaci z innych utworów literackich" (tamże: 175).

Literaturoznawcy zwracają uwagę na różne klasyfikacje bohaterów utrwalone w historii według: postaw - introwertyk, ekstrawertyk; typów charakterologicznych - melancholik, flegmatyk, piknik, sangwinik; kategorii socjologicznych artysta, chłop, mieszczanin, inteligent itd.; kategorii antropologicznych - homo faber, homo naturalis, homo loquens; zasady funkcjonalności - bohater pierwszo- i drugoplanowy. Należy w tym miejscu zaznaczyć, że postać należy do kilku klas równocześnie, i to klas o zatartych granicach (Gosk 2006: 7).

Wśród rozmaitych typologii postaci na uwagę zasługuje także spojrzenie na nie z perspektywy egzystencjalnej. Zdaniem Hanny Gosk (2006: 10) daje ona możliwość doświadczania i doznawania Innego. O bohaterze jako Innym pisze też Anna Łebkowska (2005: 238-252). Ma ona na uwadze postać odmienną kulturowo, a tym samym dyskryminowaną i wyobcowaną. Innym można również nazwać bohatera, który odczuwa swoją odmienność w związku z chorobą i izolacją od społeczeństwa czy też z brakiem spełniania oczekiwań otaczających go ludzi, nierzadko najbliższych. Rolą Innego w literaturze jest nie tylko uwrażliwienie czytelnika na drugiego człowieka, lecz także doświadczenie własnej osoby w spotkaniu z nim. Inny w tekście sprzyja też formułowaniu rozmaitych refleksji, w tym aksjologicznych. Bez względu na wielość typologii postaci jedno jest pewne - między odbiorcą tekstu a bohaterem zachodzą interakcje. Zdaniem Hansa R. Jaussa (1986: 178-191) można wydzielić następujące wzorce kontaktu, a właściwie sposoby identyfikacji czytelnika z bohaterem: asocjatywny, admirujący, sympatyzujący, kathartyczny i ironiczny.

Z różnymi postaciami literackimi obcuje młody czytelnik. Oczywiście ma on do czynienia z bohaterami zarówno pozytywnymi, jak i negatywnymi. Pozytywni są posiadaczami cech, które odbiorca powinien aprobować i traktować je jako godne naśladowania, natomiast negatywni odznaczają się cechami, których 
czytelnik nie zaakceptuje, nie stanowią one wzoru do naśladowania (Handke 2008: 206). Nie wszystkie postaci, z jakimi styka się nastolatek w literaturze dla dzieci i młodzieży, są jednoznacznie dobre i złe. Wśród nich znajdują się bohaterowie-rówieśnicy, żyjący w konkretnej rodzinie, środowisku społecznym i szkolnym, wchodzący w rozmaite relacje z najbliższymi i otoczeniem (Ignasiak-Smela 2015: 226-237; Kuliczkowska 1972: 82-87; Kuliczkowska 1985: 105-119). Często bywają oni postawieni w trudnych sytuacjach. Do tych ostatnich można zaliczyć np. przemoc fizyczną i psychiczną w rodzinie czy uzależnienia. Doświadczając bezpośrednio tego, co jest w otaczającym ich środowisku z różnych względów niewłaściwe i o czym się głośno nie mówi lub tylko obserwując takie zdarzenia, postaci próbują wyjść z zaistniałych sytuacji, odnaleźć się w nich czy przełamywać tematy tabu. Zdarza się, że zamiast kierować się wartościami, wybierają wówczas antywartości. Tym samym mogą odbiorcę tekstu prowokować do emocjonalnie nacechowanych refleksji i zabrania głosu w przedmiotowej sprawie.

O tym, że postać literacka ma spory wpływ na nastolatków, świadczą badania nad szkolnym odbiorem literatury, prowadzone przez wiele lat na wszystkich poziomach edukacji (Łazarska 2015: 196-261). Poświadczeniem tej tezy są również wyniki badań, które przeprowadziłam wśród przyszłych nauczycieli polonistów. Zredagowali oni wspomnienia na temat wpływu na nich - w dzieciństwie i w okresie szkolnym - bohaterów prozy zaadresowanej do młodych czytelników ${ }^{2}$. Spotkanie z postaciami w tego typu literaturze miało dla słuchaczy polonistyki - zarówno gdy byli nastolatkami, jak i obecnie - oprócz wartości antropologicznej także ogromne znaczenie aksjologiczne. Ich zdaniem obcowanie z bohaterami literatury dla młodzieży zawsze przynosi wiele korzyści, bez względu na wiek. Do pożytków wynikających z kontaktu dzieci i młodzieży z postaciami literackimi badani zaliczyli stymulowanie odbiorcy do namysłu nad wartościami w swoim życiu i w egzystencji innych ludzi. Będąc nastolatkami, studenci odkrywali za pośrednictwem bohaterów literackich prawdziwe znaczenie i ponadczasową rolę m.in. miłości (np. braterskiej, rodzicielskiej, ojczyzny, do Boga i Boga do człowieka), rodziny, przyjaźni, prawdy, odwagi, wolności wewnętrznej i zewnętrznej, wrażliwości na drugiego człowieka, życzliwości wobec ludzi, akceptacji i tolerancji. Zdaniem badanych postaci literackie podpowiadają młodym, jak nawiązywać i budować pozytywne relacje interpersonalne oraz

2 Badania przeprowadziłam wśród studentów jednej z krakowskich szkół wyższych. Częściowe wyniki sondażu badawczego zaprezentowałam w czerwcu 2019 roku na konferencji naukowej we Wrocławiu. W niniejszym artykule sygnalizuję wyniki jakościowej analizy wyselekcjonowanych ze zgromadzonego materiału kwestii, które nie były dotąd przedstawiane i publikowane. 
otwierać się na prowadzenie dialogu międzyludzkiego, opartego na aksjologicznie mocnych fundamentach. Prowokują nastolatka również do prowadzenia dialogu wewnętrznego. Studenci ponadto podkreślili, że już jako dorośli czytelnicy szukają w literaturze i kreacjach postaci czegoś, co otworzy ich na głębokie refleksje, m.in. nad wartościami. Co więcej, stwierdzili, że ich indywidualne spotkania z literaturą młodzieżową w czasie studiów zawsze są cenne, ponieważ sprzyjają wielokierunkowym, w tym aksjologicznym rozmyślaniom.

$\mathrm{Z}$ analizy pisemnych wypowiedzi przyszłych nauczycieli polonistów wyłania się następujący wniosek - kontakt uczniów z bohaterami literackimi, których świat wewnętrzny i zewnętrzny jest aksjologicznie lepszy od rzeczywistości, a także z postaciami borykającymi się z podobnymi problemami, zdezorientowanymi aksjologicznie i poszukującymi uporządkowania wartości w swoim wnętrzu, jest bezcenny. Obcowanie z takimi bohaterami sprzyja bowiem budowaniu pogłębionych (auto)refleksji. Przynosi też uczucie ulgi i jednocześnie wywołuje pragnienie. Oba doznania pojawiają się, jak można wnioskować na podstawie wypowiedzi badanych słuchaczy, w spotkaniu z dwiema grupami bohaterów literackich. Pierwszą stanowią postaci zdecydowanie pozytywne, czyli np. silne psychicznie, wytrwałe w miłości, przyjaźni, a także w dążeniu do każdego obranego przez siebie celu, kochające ludzi i wrażliwe na ich krzywdę, kierujące się w życiu zasadami etycznymi, a więc uczciwe, prawe, ceniące prawdę, wierne społeczeństwu, Bogu i ojczyźnie, tolerancyjne i zauroczone pięknem świata. To za ich sprawą młody czytelnik doświadcza ukojenia i spokoju, dowiaduje się bowiem, że ludzie nie są tacy źli. Odczuwany spokój wewnętrzny przeradza się w chęć wzorowania się na takich postaciach. Drugą grupę tworzą antybohaterowie, co do których nie ma wątpliwości, że w życiu nie kierują się miłością do bliźnich. Brak tej emocji powoduje, że nie mają oni wartości pozytywnych lub jest ich wyraźny niedostatek. Spotkanie z nimi, jak wskazali studenci, przynosi jednak ulgę w namyśle nad własnymi przewinieniami oraz wyzwala pragnienie podjęcia (1) refleksji nad sobą, (2) namysłu nad ludźmi i światem, w którym nastolatek żyje oraz (3) działań zmieniających na lepsze własne $J a$, swoją i innych egzystencję. Kontakt $\mathrm{z}$ antybohaterami prowokuje również do formułowania rozmyślań aksjologicznych.

Na podstawie powyższych dociekań należy uznać, że młodzi w dzieciństwie i w okresie szkolnym są otwarci na poznawanie świata wartości. Świadczą o tym też badania przeprowadzone wśród uczniów przez Małgorzatę Karwatowską (2010), Urszulę Kopeć (2008) i Magdalenę Marzec-Jóźwicką (2008). Warto dodać, że zainteresowanie wartościami i pragnienie budowania (auto)refleksji aksjologicznych nie słabnie także wśród studentów polonistyki. Wskazują na to wyżej zasygnalizowane wyniki jakościowej analizy wspomnień przyszłych 
nauczycieli oraz badania przeprowadzone przez Jadwigę Kowalikową (2008: 221-229). Wypada zatem stwierdzić, że obcowanie każdego czytelnika z literaturą, w tym z prozą „dziecięco-młodzieżową” i obecnymi w niej postaciami, jest wartością i szansą m.in. na aksjologiczne budowanie siebie.

\section{GORZKA CZEKOLADA - O POSTACIACH LITERACKICH I WAŻNYCH AKSJOLOGICZNIE SPRAWACH}

Dla różnych ludzi różne sprawy są ważne - dla jednych uroda i wysportowane ciało, dla innych posiadanie najnowszego telefonu i pieniędzy, jedni cenią sobie wiedzę, inni żeglowanie, jeszcze inni powiedzą, że najważniejsza jest miłość i rodzina. O rzeczach ważnych mówimy WARTOŚCI. (Koźmińska 2016: 9)

Powyższy cytat pochodzi ze wstępu do pierwszego tomu Gorzkiej czekola$d y$ - zbioru piętnastu opowiadań autorstwa sześciu pisarzy, wydanego w 2016 roku. Celem książki, która powstała z inicjatywy Fundacji „ABCXXI - Cała Polska Czyta Dzieciom”, jest uzmysłowienie nastoletnim czytelnikom, że we współczesnym, bardzo zmaterializowanym świecie nie można zapomnieć o tym, co w życiu powinno się liczyć najbardziej. Jest to wnętrze człowieka i posiadany przez niego drogowskaz w postaci wartości moralnych. „Dobry świat tworzą ludzie, którzy stosują wartości moralne - szacunek, odpowiedzialność, uczciwość, odwagę cywilną, sprawiedliwość, życzliwość, mądrość" (Koźmińska 2019: 7) takie słowa można przeczytać także we wstępie do drugiego tomu Gorzkiej czekolady, opublikowanego w 2019 roku. Składa się na niego tym razem trzynaście opowiadań napisanych przez pięciu autorów.

Teksty zebrane w obu publikacjach łączą zagadnienia aksjologiczne i ważne w życiu sprawy. Nie ulega wątpliwości, że w centrum zainteresowań pisarzy znajduje się młody człowiek, postrzegany w szerokim aspekcie: osobowym, obyczajowym, kulturowym i społecznym. Za sprawą kreacji bohaterów literackich twórcy utworów w różnym stopniu ukazują zasady funkcjonowania nastolatków w środowisku, w którym żyją. Prezentując zaś postaci literackie bezpośrednio i pośrednio, przedstawiają nie tylko je same, lecz także ich relacje i powiązania $\mathrm{z}$ innymi bohaterami oraz wzajemne oddziaływanie. Ponadto poddają analizie normy postępowania postaci. Rolą tych ostatnich jest otwarcie czytelników na namysł nad wartościami i przygotowanie ich do myślenia według wartości czy też doskonalenie takiego myślenia w różnych sytuacjach, jakich doświadcza współczesny młody człowiek. Warto przypomnieć, że myślenie według wartości zdaniem Tischnera (1982: 481-497) jest możliwe w spotkaniu podmiotu z drugim podmiotem. W tym przypadku chodzi o spotkanie nastolatka z człowiekiem 
w tekście literackim i o podjęcie rozważań na temat ważnych dla nich spraw. Wśród istotnych kwestii proponowanych przez autorów opowiadań, zawartych w pierwszym i drugim tomie Gorzkiej czekolady, są te związane m.in. z młodzieńczą miłością, szukaniem i pielęgnowaniem przyjaźni, potrzebą szacunku wobec siebie i drugiego człowieka, wymagającymi często sporej odwagi: uczciwością, sprawiedliwością i (współ)odpowiedzialnością. Nie brakuje także problematyki dotyczącej szeroko rozumianej przemocy, manipulacji i negatywnego wywierania wpływu na innych, odczuwania lęku przed ludźmi, niskiej samooceny.

Zdaniem Grzegorza Leszczyńskiego (2010: 188) polska literatura „dla młodych czytelników podąża przede wszystkim drogą, którą z perspektywy czytelniczej można by określić jako rozpoznawanie dróg życia młodzieży współczesnej”. Tak też warto rozpatrywać utwory zamieszczone w omawianych tomach. Młody odbiorca spotyka się w tych tekstach m.in. $\mathrm{z}$ bohaterami zbuntowanymi, aksjologicznie zagubionymi we współczesnej rzeczywistości, postawionymi w trudnej do rozwiązania sytuacji, doświadczającymi rozmaitych emocji i przeżyć w społeczności, w której funkcjonują. Jedni z nich są godni naśladowania, inni zaś są antywzorami, które nie uznają wartości i je podważają, podobnie jak normy ogólnie przyjęte i obowiązujące w rodzinie, środowisku szkolnym czy społecznym. Postaci uwikłane w mniej lub bardziej skomplikowane doświadczenia życiowe, odczuwające smutek, lęk, ale i radość, ponoszące porażki i odnoszące sukcesy mogą w różnym stopniu pobudzać nastolatków do namysłu nie tylko nad wartościami. Mają one szansę zachęcić ich do przyjęcia osobistego stanowiska wobec zdiagnozowanego problemu i stawiania pytań o własne miejsce w najbliższym otoczeniu i świecie.

Postaciami literackimi, a więc „kategorialnymi znakami poszczególnych osób lub typów ludzkich" (Kasperski 2006: 295), które mogą rozbudzić w nastoletnich czytelnikach przemyślenia aksjologiczne i ukierunkować ich na refleksję nad ważnymi sprawami, są m.in. bohaterowie Dziewczyny mistrza Katarzyny Ryrych (2019: 313-335), opowiadania zamieszczonego w drugim tomie Gorzkiej czekolady. To opowieść o Poli Kowalczewskiej, która bardzo pragnie miłości. Pragnienie to wyrasta przede wszystkim z jej głębokiego przekonania, że nie jest kochana także przez rodziców: „Nie kocha mnie, myślała, delikatnie kołysząc się w rytm melodii, nie kocha, bo jestem płaska jak deska i się garbię [...]" (tamże: 316). Spotkanie czytelnika z tą postacią zaczyna się w momencie, kiedy czternastolatka przegląda się w lustrze i dochodzi do wniosku, że nie jest taka, jak twierdził jej ojciec: „[...] wcale się nie garbi, że nie jest głupia jak gołąb ani płaska jak deska lub EKG trupa, tylko normalna...” (tamże: 315). W obecności taty zawsze „stawała się dziwnie nieśmiała i bezwolna", stawała się Inna - gorsza od reszty nastolatków, wewnętrznie wyobcowana (tamże: 315). Krytyka ojca sprawiała, że jego córka miała niskie 
samouznanie. Po przyjściu do domu z jej twarzy znikał uśmiech, podobnie zresztą jak z twarzy mamy, która po powrocie z pracy w gabinecie dentystycznym zmieniała się zupełnie, zapominając o swoich marzeniach, poczuciu humoru. Obie podporządkowywały się autorytarnemu mężowi i ojcu, który nie liczył się z ich zdaniem i znacznie przekraczał granice prywatności matki i córki.

Pozytywny obraz siebie Pola dostrzega po tym, jak zainteresował się nią dobrze zbudowany Tajson - nowo przybyły do szkoły kolega. To on wywoływał w niej przyspieszone bicie serca i zazdrość u koleżanek. W towarzystwie „nowego" - stałego bywalca siłowni czternastolatka - czuje się znakomicie. Rozpiera ją duma nie tylko z tego powodu, że ma przystojnego chłopaka, lecz także z tej przyczyny, że odkąd się spotykają, Tajson odnosi znaczące sukcesy w kulturystyce. Dość szybko młody czytelnik się orientuje, że uczucie, jakie zrodziło się między tą dwójką nastolatków, można nazwać złą miłością. Bohaterka za ukochanego, który uczęszczał do klasy wyżej, pisze wypracowania i wykonuje ćwiczenia z różnych przedmiotów, ale też kradnie ojcu lekarzowi druki recept, wypisuje na nich sterydy i podbija pieczątką. "Złota rybka Tajsona” (tamże: 317), jak o dziewczynie mówili koledzy „nowego”, z początku odczuwa lęk przed ojcem. Ma wątpliwości, czy wolno jej tak postępować. Jednak z wszelkich obaw skutecznie leczy Polę ukochany. Przekonuje ją, że to oszustwo będzie zemstą na ojcu za poniżanie, krytykowanie i surowe wychowanie córki: „To za garbienie się, myślała z satysfakcją, przybijając pieczątkę na kolejnej recepcie. A to za "płaską jak deska «, dodawała, chowając receptę do kosmetyczki" (tamże: 315). Pragnienie miłości, jakie odczuwała nastolatka, okazało się tak wielkie, że nie dostrzegła, iż Tajson ją wykorzystuje i sprzedaje wypisywane przez nią recepty. Nie tylko na tej podstawie można uznać, że deklarowane przez niego uczucie do Poli było oszustwem. „Nowy” miał również dziewczynę, o której główna bohaterka dowiaduje się przypadkowo pod koniec opowiadania. W efekcie bycie dziewczyną Tajsona kosztowało czternastolatkę utratę dobrego imienia i sporo negatywnych doświadczeń oraz wewnętrznego cierpienia. Zdała sobie z tego sprawę dopiero wtedy, gdy cała sprawa wyszła na jaw: „Boże, chyba do reszty zgłupiałam - skarciła siebie. - Boże, jak to przeżyć - i czy to kiedyś przejdzie?" (tamże: 335).

Zachowanie bohaterki, podyktowane chęcią odczuwania bliskości i bycia kochaną, może rodzić w uczniach szereg pytań. Jednym z nich będzie pytanie o przyczyny ulegania wpływom Tajsona. Ich fundamentem jest zaburzona relacja w rodzinie Poli, ponieważ jej rodzice niewłaściwie pojmowali miłość do córki. Apodyktyczny ojciec nie dostrzega w dziecku żadnych cech pozytywnych. Jest przekonany, że tylko jego zdanie się liczy. Matka, żyjąca w ciągłym strachu przed mężem, zupełnie się mu podporządkowuje i ucieka w pracę, a po powrocie do domu jest zmęczona i nie ma czasu, by porozmawiać z córką. Nastolatek może 
też zapytać o powody niewłaściwego zachowania Tajsona, który namawia Polę do oszustwa i wykorzystuje fakt, że jest nim zauroczona, a poza tym nie uznaje zasady fair play, powiązanej z transparentnością i uczciwością w sporcie. U podstaw wieloaspektowych refleksji nad przyczynami postępowania tego bohatera, dla którego miłość, odpowiedzialność i uczciwość nie są wartościami, znajdują się kwestie związane z rozumieniem autorytetu w różnych obszarach życia i jego znaczeniem dla młodego człowieka.

O czym zatem jest Dziewczyna mistrza? Kwestią zasadniczą, wokół której rozgrywają się wydarzenia, jest sposób pojmowania przez postaci literackie miłości w rodzinie, relacjach partnerskich. Bohaterowie wyrażają jednostkowe, choć bardzo różne doświadczenia ludzkie. Miłość, jak wiadomo, jest silnym uczuciem, skierowanym m.in. do drugiej osoby, łączącym bliskie sobie istoty. Nadaje sens ludzkiej egzystencji. To za jej sprawą odsłaniają się we wnętrzu człowieka inne wartości, także ukierunkowane na wartości wyższe. Te ostatnie zaś przeciwdziałają rozwojowi wszelkich działań nieetycznych. Można zatem uznać, że uczucie, jakie zrodziło się między Polą a Tajsonem, nie doskonaliło tych dwojga etycznie. Z kolei miłość ojca do córki była niewłaściwie pojmowaną troską o dziecko, które utraciło w jej wyniku poczucie własnej wartości i odczuwało brak bliskości w rodzinie. Bliskości zabrakło też między mężem a zupełnie uległą mu żoną. Ta ostatnia - bezsilna i nazbyt wystraszona kobieta, uciekająca w pracę - dopiero po dość długo trwającej psychicznej przemocy domowej postanawia skorzystać z pomocy grupy wsparcia. Uczyniła to w celu ratowania siebie i rodziny oraz by nauczyć córkę, że akceptacja złej miłości nie jest niczym dobrym (tamże: 332).

Za sprawą bohaterów Dziewczyny mistrza młodzi czytelnicy mogą pokusić się o namysł nad wieloma sprawami, ukierunkowanymi zarówno aksjologicznie, jak i antropologicznie. Należy zaliczyć do nich refleksje związane nie tylko z oceną miłości i relacji interpersonalnych w opowiadaniu, lecz także z funkcją, jakie pełni w nim każda z postaci wobec siebie nawzajem, wobec całego tekstu i wreszcie wobec jego odbiorcy. Równie ważne są rozważania na temat tego, czym jest miłość dla współczesnych nastolatków (np. celem i sensem ludzkiej egzystencji; doznaniem czegoś wielkiego, uczuciem trwającym przez całe życie lub tylko chwilę; szansą na nawiązanie bliskich kontaktów z drugim człowiekiem; czymś, co daje poczucie bezpieczeństwa). A może miłość pojmują oni wyłącznie w kategoriach siły niszczycielskiej? Istotne staną się również przemyślenia, których zabrakło bohaterom utworu, na temat zwrotności i refleksyjności, cechujących to uczucie (Tischner 2000a: 48-49), i ich roli w życiu człowieka XXI wieku, dla którego miłość zawsze powinna być wartością. Doskonałym pretekstem do rozważań są też słowa wypowiedziane do Poli przez kuratorkę: „Musisz zaczać od siebie. Musisz zbudować granice. Nauczyć się szanować i bronić siebie. Nie 
kupować uczuć ani nie żebrać o nie. Znaleźć odwagę, by odmawiać, ale też otwarcie prosić" (Ryrych 2019: 335). Szacunek do własnej osoby, budowanie siebie należy uznać za fundament związków z innymi ludźmi i pojmowania samej miłości jako pozytywnej relacji interpersonalnej. Celem tego uczucia jest bowiem rozwijanie istnienia osoby i otwieranie jej na czynienie dobra.

W świetle powyższych rozważań można, odwołując się do refleksji Edwarda Kasperskiego (1998: 40) na temat „użycia” postaci literackich w literaturze, stwierdzić, że bohaterowie tego opowiadania pełnią funkcję znaczeniotwórczą, poznawczą i modelująco-oceniającą. Pierwsza z nich dotyczy kształtowania samowiedzy antropologicznej młodych czytelników i otoczenia społeczno-kulturowego, w którym żyją. Druga wiąże się z poznawaniem, za sprawą przedstawionych postaci, typów ludzkich wraz z ich uwikłaniami interpersonalnymi, intersubiektywnymi, zdarzeniowymi. Trzecia zaś łączy się z postrzeganiem i doznawaniem przez nastolatków postaw i sposobów zachowania bohaterów wobec ludzi jako znaków wartości i/lub antywartości.

W związku z powyższym uważam, że Dziewczynę mistrza warto czytać z uczniami starszych klas szkoły podstawowej na lekcjach literatury. Szkolne spotkania z bohaterami tego utworu będą sprzyjać zarówno szukaniu odpowiedzi na wszystkie wyżej zasygnalizowane pytania oraz formułowaniu wielokierunkowych refleksji, jak i uwrażliwieniu młodych odbiorców na wartość miłości. Tym bardziej że uczucie to, jak wynika z badań empirycznych, stawiane jest przez współczesną młodzież na jednym z trzech pierwszych miejsc drabiny aksjologicznej przez nią stworzonej (Karwatowska 2012: 31-52). Postaci literackie mogą też być przyczynkiem do podjęcia i doskonalenia dyskursu o człowieku i jego kondycji aksjologicznej.

$\mathrm{Na}$ koniec tej części rozważań trzeba zaznaczyć, że również inne opowiadania zamieszczone w obu tomach Gorzkiej czekolady mogą stać się przedmiotem rozmyślań lekcyjnych jako teksty główne lub konteksty utworów literackich. Tym, co jednak może zakłócać lub nazbyt ułatwiać uczniowski odbiór wybranych do omówienia opowiadań, są wypisane wartości i/lub pojęcia z nimi związane (np. określające emocje), poprzedzające wszystkie teksty, uzupełnione w tomie drugim o rozmowę z psychologiem zamieszczoną po każdym utworze (specjalista wyjaśnia i komentuje rozpoznane w tekstach problemy). Tego typu dodatki trzeba traktować jako kontekst, który warto wykorzystać w toku lekcji, ale dopiero po pierwszym kontakcie uczniów z utworami. Wymaga to od nauczyciela wyekscerpowania z tomów wybranego utworu i przekazania go podopiecznym do czytania bez owych dopowiedzeń. Wszystko po to, aby młodzież samodzielnie spróbowała odnaleźć w literaturze to, co jest jej potrzebne w rozwoju, rozumieniu i doświadczaniu siebie, ludzi i świata, a może także we własnej terapii. 


\section{ZAKOŃCZENIE}

Lekcyjne spotkania z postaciami literackimi, w tym z bohaterami najnowszej prozy dla młodzieży, sprzyjają edukacji aksjologicznej współczesnych uczniów. Co jest jej celem? Takie kształcenie i wychowanie młodych ludzi na godzinach polskiego, które stanowi przygotowanie ich do wyboru wartości oraz do działania $\mathrm{w}$ życiu zgodnego z dokonanymi preferencjami. Przyjęte założenie jest zbieżne z poglądami polonistów - znawców przedmiotu3 . Podobnie myśli Katarzyna Olbrycht (2012: 92) - pedagog, która edukację aksjologiczną łączy z wychowaniem do wartości, czyli z przygotowaniem „człowieka do samodzielnego funkcjonowania w świecie wartości (ich dostrzegania, wybierania, porządkowania, aktualizowania, realizowania i tworzenia)". Warto pamiętać, że realizacji tego zadania wychodzi naprzeciw obcowanie uczniów z tekstami kultury. Należą do nich utwory literackie przepełnione postaciami prowokującymi odbiorcę do namysłu nad wartościami i swoim "Ja aksjologicznym". Jest ono, w rozumieniu Tischnera (2000b: 148-166), fundamentem tworzenia własnej osoby i podstawą doznawania wartości drugiego człowieka. Analizowanie i interpretowanie zachowania bohaterów, ich relacji tak z samym sobą, jak i z innymi ludźmi czy też przemyśleń postaci na temat ważnych aksjologicznie spraw przyniesie zatem korzyści w odkrywaniu przez młodzież własnej osoby.

Lekcyjne, a więc instytucjonalne obcowanie młodych ludzi z bohaterami, a co za tym idzie z literaturą, jednak nie kończy edukacji aksjologicznej. Odbywa się ona bowiem przez całe życie. Zdaniem Grzegorza Żuka (2016: 152-261) oprócz uwarunkowania instytucjonalnego, wpływającego na ową edukację, są jeszcze inne czynniki, np. rodzinne, indywidualne - mocno połączone z dojrzałością wewnętrzną i samowychowaniem oraz te związane z kulturą masową. Ma rację autor Edukacji aksjologicznej, że jest ona „procesem świadomej lub nieuświadomionej pracy nad kształtowaniem własnej osobowości, trwającym całe życie. Jest więc nie tylko »przygotowaniem do życia«, ale także nieodłącznym elementem funkcjonowania człowieka w świecie w całym okresie jego trwania" (tamże: 160). Wypada dodać, że procesem, w trakcie którego wiele dobrego mogą przynieść młodym ludziom spotkania z postaciami literackimi.

3 Zob. np. wybrane artykuły w książce pt. Wartościowanie a edukacja polonistyczna (2008). 


\section{BIBLIOGRAFIA}

Dubisz, S. (red.). (2006). Uniwersalny stownik języka polskiego. Warszawa: PWN.

Gosk, H. (2006). (O)powieść o współczesnej postaci literackiej. Polonistyka, nr 10, 6-10. Handke, R. (2008). Poetyka dzieła literackiego. Instrumenty lektury. Warszawa: PWN. Ignasiak-Smela, A. (2015). Bohater tekstów dla gimnazjalisty - dawniej i dziś. Annales Universitatis Paedagicae Cracoviensis. Studia ad Didacticam Litterarum Polonarum et Linquae Polonae Pertinentia, nr 6, 226-234.

Janus-Sitarz, A. (red.). (2008). Wartościowanie a edukacja polonistyczna. Kraków: TAiWPN Universitas.

Jauss, H.R. (1986). Wzorce interakcji w procesie identyfikacji z bohaterem. W: H. Orłowski (red.), Współczesna myśl literaturoznawcza w Republice Federalnej Niemiec (s. 178191). Warszawa: Czytelnik.

Karwatowska, M. (2010). Uczeń w świecie wartości. Lublin: Wydawnictwo UMCS.

Karwatowska, M. (2012). Autorytety w opiniach mtodzieży. Lublin: Wydawnictwo UMCS. Kasperski, E. (1998). Między poetyką a antropologią postaci. Szkic zagadnień. W: E. Kasperski, B. Pawłowska-Jądrzyk (red.), Postać literacka. Teoria i historia (s. 9-41). Warszawa: Uniwersytet Warszawski.

Kasperski, E. (2006). Świat człowieczy. Wstęp do antropologii literatury. PułtuskWarszawa: Akademia Humanistyczna im. A. Gieysztora.

Kopeć, U. (2008). Językowy obraz wartości w wypowiedziach licealistów (przyjaźń - mitość - nienawiść). Rzeszów: Wydawnictwo Uniwersytetu Rzeszowskiego.

Kowalikowa, J. (2008). Różne aspekty mówienia o wartościach i wartościowania w ramach kształcenia językowego w szkole. W: A. Janus-Sitarz (red.), Wartościowanie a edukacja polonistyczna. Kraków: TAiWPN Universitas.

Koźmińska, I. (2016). Wstęp. W: P. Beręsewicz, B. Kosmowska, W. Cesarz, A. Maleszka, K. Ryrych, K. Terechowicz, P. Królikowski, Gorzka czekolada i inne opowiadania o ważnych sprawach (s. 9). Warszawa: Prószyński i S-ka, Fundacja „ABCXXI - Cała Polska Czyta Dzieciom".

Koźmińska, I. (2019). Wstęp. W: P. Beręsewicz, K. Ryrych, K. Terechowicz, K. Majgier, K. Szymeczko, Gorzka czekolada. Nowe opowiadania o ważnych sprawach (T. 2; s. 7-8). Warszawa: Prószyński i S-ka, Fundacja „ABCXXI - Cała Polska Czyta Dzieciom".

Kuliczkowska, K. (1972). Dawne i wspótczesne problemy prozy dla dzieci. Warszawa: Wydawnictwo Universytetu Warszawskiego.

Kuliczkowska, K. (1985). Rozszerzanie świata. Wśród bohaterów współczesnej prozy polskiej i obcej. W: J. Papuzińska, B. Żurakowski (red.), Wartości literatury dla dzieci i młodzieży. Wybrane problemy (s. 107-119). Warszawa-Poznań: PWN.

Kurczab, H. (2012). Z problemów wartości i wartościowania (wybrane zagadnienia). Zeszyty Naukowe Uniwersytetu Rzeszowskiego. Seria Filologiczna. Dydaktyka, z. 72, $7-37$.

Kwiatkowska-Ratajczak, M. (1994). Z perspektywy wartości. O prozie dla dzieci i młodzieży. Poznań: Wydawnictwo Nakom.

Leszczyński, G. (2010). Bunt czytelników. Proza inicjacyjna netgeneracji. Warszawa: SBP. 
Łazarska, D. (2015). Osoba ucznia w świadomości studentów polonistyki. O zwiazku literaturoznawstwa $z$ dydaktyka. Kraków: Wydawnictwo Naukowe Uniwersytetu Pedagogicznego.

Łebkowska, A. (2005). Poznawanie siebie i poznawanie Innego. Wobec inności literatury. W: M. Czermińska, S. Gajda, K. Kłosiński, A. Legeżyńska, A.Z. Makowiecki, R. Nycz (red.), Polonistyka w przebudowie. Literaturoznawstwo - wiedza o języku - wiedza o kulturze - edukacja. Zjazd Polonistów Kraków, 22-25 września 2004 (T. 1; s. 238-252). Kraków: TAiWPN Universitas.

Markiewicz, H. (1981). Postać literacka i jej badanie. Pamiętnik Literacki, nr 2, 147-162. Markiewicz, H. (1996). Wymiary dzieła literackiego. Kraków: TAiWPN Universitas.

Marzec-Jóźwicka, M. (2008). Miłość i gimnazjaliści. Praca z tekstem kulturowym na lekcjach jezzyka polskiego. Lublin: Towarzystwo Naukowe KUL.

Olbrycht, K. (2012). Wychowanie do wartości - w centrum aksjologicznych dylematów współczesnej edukacji. Pedagogika Chrystiana, nr 29, 89-104, DOI: https://doi. org/10.12775/PCh.2012.005.

Ryrych, K. (2019). Dziewczyna mistrza. W: P. Beręsewicz, K. Ryrych, K. Terechowicz, K. Majgier, K. Szymeczko, Gorzka czekolada. Nowe opowiadania o ważnych sprawach (T. 2; s. 312-335). Warszawa: Prószyński i S-ka, Fundacja „ABCXXI - Cała Polska Czyta Dzieciom".

Tischner, J. (1982). Myślenie wedtug wartości. Kraków: Znak.

Tischner, J. (2000a). Mitość nas rozumie. Rok liturgiczny z księdzem Tischnerem. Kraków: Znak.

Tischner, J. (2000b). Świat ludzkiej nadziei. Kraków: Znak.

Wiśniewski, R. (1989). Podstawy aksjologii Władysława Tatarkiewicza. W: Z. Czarnecki, S. Soldenhoff (red.), Człowiek $i$ wartości moralne. Studia z dziejów polskiej myśli niezależnej (s. 289-312). Lublin: Wydawnictwo Lubelskie.

Żuk, G. (2016). Edukacja aksjologiczna. Zarys problematyki. Lublin: Wydawnictwo UMCS. 